\title{
CRITICAL THOUGHTS ON THE IMPLICATIONS OF BREXIT FOR PROCEDURAL ENVIRONMENTAL RIGHTS IN THE UNITED KINGDOM
}

\author{
UZUAZO ETEMIRE* \\ Senior Lecturer \\ University of Port Harcourt, Nigeria \\ uzuazo.etemire@uniport.edu.ng
}

Recibido: 23 de noviembre de 2017 / Aceptado: 24 de enero de 2018

\begin{abstract}
In 2016, the UK held a referendum in which voters elected to leave the EU. The two-year process is already underway. This move is however raising a lot of concerns about its implication for environmental regulation in the UK post-Brexit. Indeed, these concerns are fuelled by the substantial contribution of the EU to the development of environmental law in the UK since the latter became a member of the Union in 1973. This article is a contribution to this discourse. It primarily attempts to unravel the implications of Brexit for the future of procedural environmental rights in the UK, among other related issues that will receive some exposition. It is hoped that this will be a step towards understanding more clearly and preparing better for the postBrexit era with respect to securing and progressing, as much as possible, procedural environmental rights in the UK.
\end{abstract}

RESUM: El 2016, el Regne Unit va celebrar un referèndum en què els votants van triar sortir de la UE. El procés, que durarà dos anys, ja està en marxa. No obstant això, aquesta mesura planteja moltes qüestions sobre la implicació en la regulació ambiental al Regne Unit després del Brexit. De fet, aquestes preocupacions s'intensifiquen amb la contribució substancial de la UE al desenvolupament del dret ambiental al Regne Unit

\footnotetext{
${ }^{*}$ I will like to thank the Coimbra Group for the award of a scholarship that enabled me successfully undertake this research at the Faculty of Law, University of Barcelona. I am also grateful to Professors Mar Campins Eritja and Alexandra Penalver Cabre for their helpful comments on initial drafts of this article. The usual caveat applies
}

[DOI: https://doi.org/10.17345/1869] 
des que aquest es va convertir en membre de la Unió el 1973. Aquest article és una contribució a aquest discurs. Intenta desentranyar principalment les implicacions del Brexit en el futur dels drets processals del medi ambient al Regne Unit, entre altres temes relacionats que també s'hi tractaran en certa manera. S'espera que aquest sigui un pas cap a una comprensió més clara i que ens prepari millor per a l'era post-Brexit pel que fa a assegurar i avançar, en la mesura que sigui possible, els drets processals del medi ambient al Regne Unit.

RESUMEN: En 2016, el Reino Unido celebró un referéndum en el que los votantes eligieron salir de la UE. El proceso, que durará dos años, ya está en marcha. Sin embargo, esta medida plantea muchas cuestiones sobre su implicación en la regulación ambiental en el Reino Unido después del Brexit. De hecho, estas preocupaciones se intensifican con la contribución sustancial de la UE al desarrollo del derecho ambiental en el Reino Unido desde que este se convirtió en miembro de la Unión en 1973. Este artículo es una contribución a este discurso. Intenta desentrañar principalmente las implicaciones del Brexit en el futuro de los derechos procesales del medio ambiente en el Reino Unido, entre otros temas relacionados que también se trataran en cierta manera. Se espera que este sea un paso hacia una comprensión más clara y que nos prepare mejor para la era posbrexit con respecto a asegurar y avanzar, en la medida de lo posible, los derechos procesales del medio ambiente en el Reino Unido.

KEYWORDS: Brexit - European Union - Environmental Procedural Rights Access to Environmental Information - Participation in Environmental Decisionmaking - Access to Justice in Environmental Matters - Aarhus Convention.

PARAULES CLAU: Brexit - Unió Europea - Dret processal ambiental - Accés a la informació ambiental - Participació en la presa de decisions ambientals - Accés a la justícia en assumptes ambientals - Conveni d'Aarhus.

PALABRAS CLAVE: Brexit - Unión Europea - Derecho procesal ambiental Acceso a la información ambiental -Participación en la toma de decisiones ambientales - Acceso a la justicia en asuntos ambientales - Convenio de Aarhus. 
SUMMARY: I. Introduction. II. Access to Environmental Information. III. Participation in Environmental Decision-Making Processes. IV. Access to Justice in Environmental Matters. V. Some Cross-Cutting Issues. VI. Conclusion. VII. References.

\section{INTRODUCTION}

The result of a referendum held in the United Kingdom (UK) in June 2016 revealed that about $52 \%$ of voters were in favour of the UK exiting the European Union (EU). ${ }^{1}$ On this basis, the UK government triggered Article 50 of the Treaty of the $\mathrm{EU}^{2}$ - the twoyear process for leaving the EU - and is scheduled to depart the Union in March $2019 .{ }^{3}$ Whilst these moves formally signify the beginning of the end of the UK's membership of the EU, they equally raise serious concerns about the major implications of Brexit $^{4}$ for the future of environmental law and governance in the UK. ${ }^{5}$ These concerns are rightly fuelled by the fact the EU has played a most crucial and profound role, since the UK joined the EU in $1973,{ }^{6}$ in radically transforming and progressing UK environmental law and policy. ${ }^{7}$ In fact, about $80 \%$ of UK environmental legislation is said to have their roots in obligations under EU law. ${ }^{8}$

Indeed, the potency of EU environmental law is not without some criticism and shortcomings. Regrettably, to a substantial extent, EU environmental law is driven, shaped - and sometimes restricted - by economic considerations underpinning the

1 ASTHANA, A., QUINN, B. and MASON, R. 'UK Votes to Leave EU after Dramatic Night Divides
Nation', $\quad$ The $\quad$ Guardian, $\quad 24 \quad$ June https://www.theguardian.com/politics/2016/jun/24/britain-votes-for-brexit-eu-referendum-david-cameron.

2 [2012] OJ C 326/1.

${ }^{3}$ Although the UK is presently making effort to negotiate an addition two-year 'transition' period, the idea is yet to be accepted by the EU. ASTHANA, A. and MASON, R., 'Theresa May asks EU for twoyear Brexit Transition Period', The Guardian, 22 September 2017, available at: https://www.theguardian.com/politics/2017/sep/22/theresa-may-asks-eu-for-two-year-brexit-transitionperiod.

4 'Brexit' is a shorthand way of referring to Britain exiting the EU.

5 See RODGERS, C. 'ELR opinion issue 3 2016: BREXIT: What implications for land use and the natural environment?', Environmental Law Review, vol. 18, num. 1 2016, p. 187.

${ }^{6}$ See, Treaty concerning the accession of the Kingdom of Denmark, Ireland, the Kingdom of Norway and the United Kingdom of Great Britain and Northern Ireland to the European Economic Community and to the European Atomic Energy Community [1972] OJ L73/5, Art 2. (Norway decided not to join the Union after the treaty was agreed.)

7 House of Commons Environmental Audits Committee, 'EU and UK Environmental Policy' (Third Report of Session 2016-17, House of Commons, April 2016) 8-9.

${ }^{8}$ House of Commons Environmental Audits Committee, 'The Future of the Natural Environment after the EU Referendum' (Sixth Report of Session 2016-17, House of Commons, January 2017) 15. 
single market as much as by an environmentalist agenda. ${ }^{9}$ It is quite clear that this is born out of the EU's extensive preoccupation with sustainable growth compared with its sustainable development agenda. ${ }^{10}$ Yet, the positive impact of EU environmental law and mechanisms in considerably and markedly advancing environment rights and protection in the UK is widely hailed and acknowledged. Indeed, there are specific and concrete UK examples of wild birds' protection and diverse habitat conservation, as well as significant improvements in air quality, bathing water, waste disposal, among other, as a result of the variety of EU Directives applicable to these issues. ${ }^{11}$

To be sure, the same can be said of and applies to procedural environmental rights in the UK, which constitute the major thematic focus of this article. Undeniably, the public right to access information, participate in decision-making and access justice in environmental matters have been bolstered over the years by several EU measures either obliging states to adopt necessary implementing legal regimes, ${ }^{12}$ or creating procedures conferring and enabling the exercise of those rights beyond the national level. ${ }^{13}$ Of course, the UK (as well as the EU) is party to the UN Economic Commission for Europe (UNECE) Convention on Access to Information, Public Participation in Decision-Making, and Access to Justice in Environmental Matters ${ }^{14}$ (Aarhus Convention). Therefore, its non-compliance with the provisions of the Convention can be tested by the public before the Convention's Compliance Committee, whose recommendations though non-binding, are authoritative interpretations of the

\footnotetext{
${ }^{9}$ LEE, R. G., 'Always Keep a Hold of the Nurse: British Environmental Law and Exit from the European Union', Journal of Environmental Law, num. 29, 2017, pp. 156 - 158.

${ }^{10}$ Ibid. See generally, JACKSON, T., Prosperity without Growth: Economics for a Finite Planet, Routledge, 2016.

${ }^{11}$ See THE WILDLIFE TRUST, 'A Guide to Key European Environmental 'Directives', available at: http://www.wildlifetrusts.org/EU-impact; and House of Commons Environmental Audits Committee $o b$. cit., p. 9.

${ }^{12}$ Examples of UK-applicable EU legislation obliging member states to guarantee at the domestic level the public right to information, participation in decision-making and access to justice in environmental matters, include: Directive 2003/4/EC on public access to environmental information [2003] OJ L41/26; Directive 2010/75/EU on industrial emissions (integrated pollution prevention and control) [2010] OJ L334/17; and Directive 2011/92/EU on the assessment of the effects of certain public and private projects on the environment [2012] OJ L26/1 (as amended).

${ }^{13}$ See for example: European Commission (EC) Regulation No 1367/2006 on the application of the provisions of the Aarhus Convention on Access to Information, Public Participation in Decision-making and Access to Justice in Environmental Matters to Community institutions and bodies [2006] OJ L264/13; and Treaty on the Functioning of the European Union (TFEU) [2012] C 326/01, Art 258, that creates an opportunity for public access to justice (in environmental matters) at the EU level through the $\mathrm{EC}$ and the CJEU.
}

${ }^{14} 25$ June 1998, 2161 UNTS 447. 
Convention's provisions which must be taking into consideration by domestic authorities and courts in giving effect to the Convention, ${ }^{15}$ and can also be a source of embarrassment to the government. ${ }^{16}$ However, it is EU laws on the subject that provide the 'hard, [legally] enforceable edge... to the Aarhus Conventions provisions' that has majorly propelled the UK to better observance of the Convention's norms. ${ }^{17}$

Whilst the writings of environmental law scholars have so far focused mostly on the implications of Brexit for the future of UK environmental law in general, and sometimes heavily on the substantive aspect, this article takes a somewhat different turn to the subject. ${ }^{18}$ The major aim of this article is to critically and specifically reflect on the implications of Brexit for procedural environmental rights as they apply to the UK and for its benefit. To varying extents and as applicable, the article will unravel the restrictions, challenges, uncertainties, as well as opportunities and possibilities which Brexit may present to the UK as regards the continued exercise and development of procedural environmental rights. It is hoped that this will at least be a step towards understanding more clearly and preparing better for the post-Brexit era with respect to securing and progressing, as much as possible, procedural environmental rights in the UK.

Already, the UK government has firmly demonstrated its intention to retain or incorporate into domestic law all existing UK-applicable EU (environmental) laws through its current European Union (Withdrawal) Bill 2017 - 2019. ${ }^{19}$ Hence, this article does not focus on laws and rights covered there under, except to the extent that it raises a spectacular issue worth reflecting on. Also, one is mindful of the fact that at the time

${ }^{15}$ Decision I/7 Annex XII-37 (UN Doc ECE/MP.PP/2/Add.8). This is point has been confirmed by the UK Supreme Court in the case of Walton v Scottish Ministers [2012] UKSC 44 per Lord Carnwath, para. 100: 'Although the [Aarhus] Convention is not part of domestic law as such (except where incorporated through European directives), ...the decisions of the Committee deserve respect on issues relating to standards of public participation.'

${ }^{16}$ ReID, C. 'Procedural Rights', in CARDESA-SALZMANN, A. and SAVARESI, A. The Implication of Brexit for Environmental Law in Scotland, Scottish Universities Legal Network on Europe, December 2016, pp. 9-10.

${ }^{17} \mathrm{Ibid}$.

${ }_{18}$ Apart from other articles used in the course of this work, see the following studies for example: BARLOW M. and HADLEY, E. 'Effects of a Brexit on Environmental Laws: Habitats, Waste, Chemicals and Air', Burges and Salmon, April 2016; IMRIE, C. 'Scotland After Brexit: Environmental Law', University of Strathclyde International Public Policy Institute, May 2017; TROMANS, S. and BOWDEN, P. 'Brexit and Environmental Law: Exit from the Euratom Treaty and its Environmental Implications', UK Environmental Law Association, July 2017.

${ }^{19}$ Available at: https://services.parliament.uk/bills/2017-19/europeanunionwithdrawal.html. Some aspects of this Bill, but not the 'savings' aspect, is still currently been debated in the UK Parliament. 
of writing, more detailed negotiations on Brexit are ongoing between the UK government and the EU. ${ }^{20}$ Thus, effort has been made to maintain a broad discussion within the ambits of some of the widely accepted and known implications of Brexit for the future relationship between the UK and EU laws and institutions. ${ }^{21}$ That said, the analysis below is executed under the three pillars of procedural environmental rights public right to access environmental information, participate in decision-making processes, and access justice in environmental matters - with a last major section touching on cross-cutting issues that affect all the aforementioned rights.

\section{ACCESS TO ENVIRONMENTAL INFORMATION}

The public right and opportunity to access environmental information, as earlier alluded to, is an aspect of UK law that has been progressed by EU law over the years. Consequently, the expectation is that aspects of this pillar of UK environmental procedural rights would be impacted and curbed by UK exist from the EU. However, this may not entirely be the case.

Apart from the fact that the UK is bent on retaining its domestic EU-inspired access to environmental information legislation as noted above, ${ }^{22}$ the $\mathrm{UK}$ public will continue to have wide access to environmental information held by EU institutions post-Brexit. This is on the basis of European Commission (EC) Regulation No 1367/2006 on the application of the provisions of the Aarhus Convention on Access to Information, Public Participation in Decision-making and Access to Justice in Environmental Matters

\footnotetext{
${ }^{20}$ HUNTER, A. and WHEELER, B., 'Brexit: All you need to know about the UK leaving the EU', $B B C$, 26 October 2017, available at: http://www.bbc.com/news/uk-politics-32810887.

${ }^{21}$ Of course, no one knows for sure the exact nature of the relationship between the UK and the EU postBrexit, or the exact extent to which the UK plans to, or would eventually distance itself from the EU (and this should not stop or prevent analysis of the issue). SAVARESI, A. 'Brexit Scenarios', in CARDESASALZMANN, A. and SAVARESI, A., ob. cit., pp. $2-3$. What is however known is that the UK has no plan to negotiate an agreement with the EU that will undermine the essence of Brexit in the first place. It is taking the stand that 'Brexit means Brexit', and that the UK will neither be part of the EU single market and customs union nor be subject to core EU institutions anymore as though it were still a member of the Union (and it is mainly in this light that the discussion in this paper is executed). See, respectively, the full texts of the British Prime Minister's letter to the European Council president, Donald Tusk, triggering Art 50, and her Florence speech setting out the UK's post-Brexit plans: BBC, 'Brexit: The UK's letter triggering Article 50', BBC, 29 March 2017, available at: http://www.bbc.com/news/uk-politics39431070; and Gov.UK, 'PM's Florence Speech: A New Era of Cooperation and Partnership between the UK and the EU', Gov.UK, 22 September 2017, available at: https://www.gov.uk/government/speeches/pms-florence-speech-a-new-era-of-cooperation-andpartnership-between-the-uk-and-the-eu.

22 That is, the Environmental Information Regulation 2004 (No. 3391), and the Environmental Information (Scotland) Regulations 2004 (No. 520).
} 
to Community institutions and bodies (Aarhus Regulation), ${ }^{23}$ which guarantees the right of the public ${ }^{24}$ (without any form of discrimination as to citizenship, nationality or domicile) to access environmental information held by EU institutions or bodies. ${ }^{25}$ Indeed, the possibility of continued access to EU regional environmental information is vital for the UK public and businesses in making broad-based and far-reaching strategic decisions. It is also important considering the polycentric nature of environmental issues (and the need to understand them), as substantiated by the primary law of ecology that 'everything is connected to everything else', ${ }^{26}$ and the fact that 'in nature all ecosystems are inextricably intertwined. ${ }^{27}$

However, access to EU chemical-related environmental information appears to be an exception to this straightforward continued public right of access to the general EU environmental information post-Brexit. Under Aarhus Convention, Parties are softly obliged to 'encourage operators whose activities have a significant impact on the environment to inform the public regularly of the environmental impact of their activities and products, where appropriate within the framework of voluntary ecolabelling or eco-auditing schemes or by other means. ${ }^{28}$ An EU law which to an extent implements this provision is the EC Regulation No 1907/2006/EC concerning the Registration, Evaluation, Authorisation and Restriction of Chemicals (REACH) ${ }^{29}$ Part of the purpose of this Regulation is 'to ensure a high level of protection of human health and the environment ${ }^{30}$ with respect to the handling and use of chemicals. Hence, an important element of the regime is its information gathering and communication requirement which seeks to ensures that producers, importers and consumers (whether users or distributors) have the information they need - 'relating to health, safety and

\footnotetext{
23 [2006] OJ L 264/13. This Regulation was adopted to bring the EU as a body in compliance with its obligations under the Aarhus Convention, as the EU is a Party to the treaty.

24 EC Regulation No 1367/2006, Art 2 (1)(b) defines 'the public' as 'one or more natural and legal persons, and associations, organisations or groups of such persons.'

${ }^{25}$ EC Regulation No 1367/2006, Art 1 (1)(a).

${ }^{26}$ See COMMONER, B., The Closing Circle: Confronting the Environmental Crisis, Jonathan Cape Ltd, 1972 , p. 33

27 DEHAN, A. 'An International Environmental Court: Should there be One?', Touro Journal of Transnational Law, num. 2, 1992, p. 31.

${ }^{28}$ Aarhus Convention, Art 5 (6).

29 [2006] OJ L396/1.

${ }^{30}$ REACH Regulation, Art 1 (1).
} 
environmental properties, risks and risk management measures' - to use chemicals safely. ${ }^{31}$

The European Chemical Agency (ECHA), a creation of the REACH Regulation, is charged with implementing this Regulation, including providing information on chemicals, among others. ${ }^{32}$ Apart from information placed online by the ECHA for the general public, ${ }^{33}$ access to others documents held by the ECHA is expressly made subject to the provisions of EC Regulation No 1049/2001regarding public access to European Parliament, Council and Commission documents ${ }^{34}$ which only grants the right of access to citizens and residents of EU member states. ${ }^{35}$ However, regarding access to environmental information, Article 3 of the Aarhus Regulation has extended the application of EC Regulation No 1049/2001 as follows:

Regulation (EC) No 1049/2001 shall apply to any request by an applicant for access to environmental information held by Community institutions and bodies without discrimination as to citizenship, nationality or domicile and, in the case of a legal person, without discrimination as to where it has its registered seat or effective centre of its activities.

Whilst the above provision seems to preserve the right of the UK public and businesses to access environmental information held by the ECHA post-Brexit, it arguably appears from Article 120 of the REACH Regulation that the UK government as a non-EU state would need to do a bit more - in terms of negotiate and reaching a special agreement with the EU - to make that a reality. ${ }^{36}$ Additionally, to prevent the risk of regulatory

\footnotetext{
${ }^{31}$ European Commission - Environment Directorate General, 'REACH in Brief' (October 2007) 10, available at: http://ec.europa.eu/environment/chemicals/reach/pdf/publications/2007_02_reach_in_brief.pdf. See for example also, REACH Regulation, Art 7.

${ }^{32}$ See the ECHA website: https://echa.europa.eu/about-us/who-we-are/mission.

${ }^{33}$ See REACH Regulation, Art 119.

${ }^{34}$ [2006] OJ L 396.

${ }^{35}$ REACH Regulation, Art 118. According to Arts 2 (1) of EC Regulation No 1049/2001, 'Any citizen of the Union, and any natural or legal person residing or having its registered office in a Member State, has a right of access to documents of the institutions, subject to the principles, conditions and limits defined in this Regulation'. EU institutions, in accordance with Art 2 (2) of EC Regulation No 1049/2001, may however 'grant access to documents to any natural or legal person not residing or not having its registered office in a Member State' on a discretionary basis. And from the definition of 'documents' in the Art 3 (a) of the Regulation, there is no doubt that it includes environment-related information: "documents' shall mean any content whatever its medium (written on paper or stored in electronic form or as a sound, visual or audiovisual recording) concerning a matter relating to the policies, activities and decisions falling within the institution's sphere of responsibility.'
}

${ }^{36}$ Art 120 of REACH Regulation provides thus: 'Notwithstanding Articles 118 [on access to information] and 119 [on electronic public access], information received by the Agency under this Regulation may be 
uncertainty and ensure continued access of UK chemical to EU market and maintain in some form the current REACH obligations, especially those pertaining to information generation and communication, there will be need for a new UK chemical legislation translating, as much as possible, provisions of the REACH Regulation into UK domestic law (as the Regulation is at the moment directly applicable to the UK without any domestic enactment). ${ }^{37}$ Such a development, according to scholars like Lee ${ }^{38}$ and Roger, ${ }^{39}$ would likely also require a new domestic governance structure, including new administrative capacity and scientific expertise to make up for the gaps in chemical regulation that will unravel post-Brexit. ${ }^{40}$

\section{PARTICIPATION IN ENVIRONMENTAL DECISION-MAKING PROCESSES}

The opportunity to participate in environmental decision-making processes is another procedural area where members of the public and civil society groups in the UK may witness some changes post-Brexit. The Aarhus Convention, apart from requiring public participation in decisions on specific activities, ${ }^{41}$ also obliges parties (like the UK) to ensure public participation in the preparation of plans, programmes and policies related to the environment, ${ }^{42}$ and during the preparation of all legally binding normative

disclosed to any government or national authority of a third country or an international organisation in accordance with an agreement concluded between the Community and the third party concerned under Regulation (EC) No 304/2003 of the European Parliament and of the Council of 28 January 2003 concerning the export and import of dangerous chemicals (1) or under Article 181a(3) of the Treaty, provided that both the following conditions are met: (a) the purpose of the agreement is cooperation on the implementation or management of legislation concerning chemicals covered by this Regulation; (b) the third party protects the confidential information as mutually agreed.

37 This is because the UK being a member of the EU did not require domestic legislation to make the REACH Regulation operable in the UK, as the latter was directly applicable and binding in the UK. Hence, the UK plan of 'saving' existing EU law that has been transposed into UK law through the EU (Withdrawal) Bill, or the 'Great Repeal Bill' as it is popularly called, would require it to make new laws where the country had relied on directly applicable EU legislation like the REACH Regulation. See SCOTFORD, E. and BOWMAN, M., 'Brexit and Environmental Law: Challenges and Opportunities', King's Law Journal, vol. 27, num. 3, 2016, pp. 416-417.

${ }^{38}$ LEE, R. G., ob. cit., p. 162.

${ }^{39}$ ROGER, A. 'Chemicals', in CARDESA-SALZMANN A. and SAVARESI, A., ob. cit., p. 13.

${ }^{40}$ Indeed, as acknowledged within the UK government, '[s]ome legislation will be difficult to transpose into UK law, and will require new governance arrangements to be established'. House of Commons Environmental Audits Committee, ob. cit., p. 3.

${ }^{41}$ Aarhus Convention, Art 6.

${ }^{42}$ Ibid, Art 7. 
rules. ${ }^{43}$ Article $3(5)^{44}$ and $(6)^{45}$ however establishes that the Convention is 'a floor, not a ceiling, ${ }^{46}$ as Parties retain the right to maintain or introduce broader participatory rights and opportunities than those obtainable under the Convention. But, as it appears, Brexit will cause the UK to 'backslide' with respect to maintaining certain EU-enabled public rights and opportunities to participate in environment-related decision-making that seemingly go beyond the requirements of the Aarhus Convention.

Under EU arrangements, beyond the preparation of environmental laws, there 'are the routine requirements in EU legislation that government plan the implementation of environmental obligations and report on progress. This enables political and legal, formal and informal, peer and citizen, scrutiny of government action. ${ }^{47}$ This requirement for the UK to send government environmental plans and reports to the EC - which plays a key role in ensure the appropriate application of EU laws as 'guardian of the Treaties' according to Article 17 of the TEU - will cease to apply post-Brexit, ${ }^{48}$ and the consequential opportunity for the public to engage the government on their actions will be lost. This loss might be considered a bit significant, given that the participation platform is not just a national, but a regional one that provides for external and independent scrutiny of government actions by the EC together with public involvement at that level. And even though the UK may not be in breach legally of relevant obligations under the Aarhus Convention post-Brexit, this deterioration of participatory right and opportunity will be considered an action that did not promote the tenets of the Convention, but went against the spirit of the regime.

Indeed, the Aarhus Convention Compliance Committee conceded (in a matter involving Hungary) that Article 3 (6) 'did not... completely exclude a possibility of [a Party] reducing existing rights [and opportunities] as long as they did not fall below the level

\footnotetext{
${ }^{43}$ Ibid, Art 8.

44 Art 3 (5) provides that: "The provisions of this Convention shall not affect the right of a Party to maintain or introduce measures providing for broader access to information, more extensive public participation in decision-making and wider access to justice in environmental matters than required by this Convention.'

${ }^{45}$ Art 3 (6) provides that: 'This Convention shall not require any derogation from existing rights of access to information, public participation in decision-making and access to justice in environmental matters.'

46 EBbesson, J., GAUGITSCH, H., JENDROSKA, J., MARShAll, F. and STEC, S., The Aarhus Convention: An Implementation Guide, $2^{\text {nd }}$ ed., United Nations, 2014, p. 67.

${ }^{47}$ LEE, M. 'Accountability for Environmental Standards after Brexit' Environmental Law Review, vol. 19, num. 2, 2017, pp. 89-90.

${ }^{48}$ Ibid.
} 
granted by the Convention. ${ }^{49}$ The Committee nevertheless posited that the wordings of Articles 3 (6) and (5) taken together with Article 1, ${ }^{50}$ 'indicate that such reduction was not generally perceived to be in line with the objective of the Convention. ${ }^{51}$ So strongly the Committee felt about this that it recommended that the Meeting of Parties (MoP) should 'urge Parties to refrain from taking any measure which would reduce existing [participatory] rights... even if such measures would not necessarily involve any breach of the Convention and should recommend to Parties having already reduced existing rights to keep the matter closely under review, ${ }^{52}$ (but the MoP did not act on the recommendation in its meeting that followed ${ }^{53}$ ).

What is more, with Brexit, the UK will assume new law-making responsibilities concerning environmental issues over which the EU presently exercises legislative powers. Consequentially, the UK public will then have the opportunity of participating in law-making as it concerns the affected areas. 'These powers [which are currently under the remit of the EU] are wide-ranging, and cover subjects as diverse as agriculture, air quality, chemicals, climate change, fisheries, protected areas and waste'; and the major approach of the EU in regulating these concerns is such that some of its legislation 'applies directly, mostly without any discretion left to the Member States' and others 'generally set compulsory objectives for Member States, leaving them discretion in deciding how to comply. ${ }^{54}$ These EU environmental laws are commonly made with very limited possibility for wide public input; for example, for possible participation in such a law-making process, the EU established a 32-member consultative committee on environmental affairs (made up of few representatives from environmental NGO and others handpicked by the EC. $)^{55}$

\footnotetext{
${ }^{49}$ Hungary ACCC/C/2004/4; ECE/MP.PP/C.1/2005/2/Add.4, 14 March 2005, para 18.

${ }^{50}$ Article 1 contains the Objective of the Convention thus: 'In order to contribute to the protection of the right of every person of the present and future generations to live in an environment adequate to his or her health and well-being, each Party shall guarantee the rights of access to information, public participation in decision-making, and access to justice in environmental matters in accordance with the provisions of this Convention.'

${ }^{51}$ Hungary, ob. cit., paras 17 and 18.

52 Ibid, para 21.

53 See for example, Report of the Second Meeting of the Parties to the Aarhus Convention, ECE/MP.PP/2005/2/Add.6 (decision II/5), 25-27 May 2005, para 3.

54 ROGER, A. 'Types of EU Environmental Legislation and Competence Allocation' in CARDESASALZMANN, A. and SAVARESI, A., ob. cit., p. 5.

${ }^{55}$ See EBBESSON, J. et al., ob. cit., p. 184; and EC Decision 97/150/EC of 24 February 1997. For what is arguably, to a limited extent, a contrast to this view in a special case, see: HEYVAERT, V., 'Aarhus to
} 
But that will change for the UK post-Brexit, as participation at the EU level does not favourably compare with the relatively wider and more robust provision for public participation in law-making in the UK. ${ }^{56}$ Unlike the EU procedure that is much farther from the public given its regional nature (which makes it administratively difficult, if not practically impossible, to traditionally allow for detailed and meaningful participation from the EU public), this UK procedure is closer to the people and comprises both informal and formal consultations/public hearings involving members of the public in general. ${ }^{57}$

In fact, the current position of things in the UK (and indeed other EU countries), where the general public have no right or effective opportunity to meaningfully participate in the formation of EU laws and binding objectives with environmental implications that directly apply to their country, may arguably not be in compliance with Article 8 of the Aarhus Convention which obliges parties to 'take concrete measures' ${ }^{58}$ to ensure that the public has a say in the making of laws that affect the environment. From the standpoint of the Aarhus Convention, it can be argued that this is a natural 'Achilles heel' of the EU (environmental) regulatory system, effective as some of its measure might have been. Thus, as it appears, Brexit carries with it the implication of giving the UK a chance for better compliance with its Article 8 obligation. And this is in tune with Lee's caution against 'too great a nostalgia' as the UK leaves the EU considering the possibility for some positive change to UK environmental law which Brexit opens up. ${ }^{59}$ Nonetheless, one should not overlook the subsidiarity issue which this future change that is, the transfer of new environmental law-making powers from the EU to the UK raises. Generally, according to the widely recognised 'principle of subsidiarity' (although many variations exist $\left.{ }^{60}\right)$, (environmental) decisions are best made and should

Helsinki: Participation in Environmental Decision-Making on Chemicals', in PALLEMAERTS, M. (ed), The Aarhus Convention at Ten: Interactions and Tensions between Conventional International Law and EU Environmental Law, Groningen: Europa Law Publishing, 2011, pp. 189 - 211.

56 See MIKULI, P. and KUCA, G. 'The Public Hearing and Law-Making Procedure', Liverpool Law Review, num. 37, 2016, pp. 1-17.

57 OECD, 'Background Document on Public Consultation', 3, available at: https://www.oecd.org/mena/governance/36785341.pdf; and Gov.UK, 'An overview of the Process by which Bills become Law' (20 February 2013) available at: https://www.gov.uk/guidance/legislativeprocess-taking-a-bill-through-parliament.

${ }^{58}$ EBBESSON, J., et al., ob. cit., p. 184.

${ }^{59}$ LEE, R. G., ob. cit., p. 155.

60 See generally, FOLLESDAL, A. 'The Principle of Subsidiarity as a Constitutional Principle in International Law’, Global Constitutionalism, vol. 2, num. 1, 2013, pp. 37-62. 
be made at the lowest possible level of governance where they will be sufficiently effective. ${ }^{61}$ Essentially, this principle, which bears similarity with that of 'shared responsibility,' is 'not so much of a choice of action at one level to the exclusion of others but, rather, a mixing of actor and instruments at the appropriate levels. ${ }^{62}$ It was partly on this basis that certain environmental decisions were left to EU member states, and others placed within the remit of EU lawmakers where the objectives of the required action cannot be sufficiently achieved by the member states but only at the EU level given the required scale and effects of the proposed action. ${ }^{63}$ The implementation of this 'co-responsibility' tool - in the words of the UNDP - is how one increases 'the overall quality and effectiveness of the system of [environmental] governance, while increasing the authority and capacities of [lower authorities]. ${ }^{, 64}$

Hence, it might arguably be more effective for the UK to have the free hand to legislate (with the meaningful participation of the public) on certain environmental issues with at most a negligible transboundary element to them, like urban noise or household waste, that have so far been partly legislated on by the EU. ${ }^{65}$ But then, the contrary is the case with respect to other environmental problems having a major transboundary character, such as climate change, ozone depletion and water pollution, which comparatively can better receive effective solution at the EU level, and not exclusively at the level of member states. ${ }^{66}$ This is so, given the harmonising force of the EU in an interconnected world that requires collective state action to effectively address many major

61 See VAN ZEBEN, J. 'Subsidiarity in European Environmental Law: A Competence Allocation Approach', Harvard Environmental Law Review, num. 38, 2014, pp. 415-464; and Definition of Subsidiary in Oxford English Dictionary, available https://en.oxforddictionaries.com/definition/subsidiarity.

${ }^{62}$ Fifth Environmental Programme of Action (OJ 1993 C138/1) Chapter 8.

${ }^{63}$ See TEU, Art 5(3); Protocol (No 1) On the Role of National Parliaments in the European Union (OJ, 2016/C 202/01); Protocol (No 2) On the Application of the Principles of Subsidiarity and Proportionality (OJ, 2016/C 202/01); and BRINKHORST, L. 'Subsidiarity and European Community Environmental Policy: A Pandora's Box’, European Environmental Law Review, 1993, p. 20.

64 UNDP, 'Decentralization: A Sampling of Definitions' (October, 1999) 2, available at: http://web.undp.org/evaluation/documents/decentralization_working_report.PDF.

65 See EC Directive 2008/98/EC of 19 November 2008 on waste (OJ, L 312/3); and EC Directive 2002/49/EC of 25 June 2002 relating to the assessment and management of environmental noise (OJ, L 189/12).

66 See DE SADELEER, N. 'Principle of Subsidiarity and the EU Environmental Policy', Journal of European Environmental and Planning Law, vol. 9, num. 1, 2012, p. 64. 
environmental challenges, ${ }^{67}$ apart from the fact that the EU takes a leading role in international negotiations on such areas as climate change. ${ }^{68}$ And while the UK will continue to have its choices and decisions (on transboundary issues) constrained by norms generated from other European platforms (such as the Council of Europe and the UN Economic Commission for Europe) and the provision of international environmental treaties, ${ }^{69}$ the arguably more effective EU power of constraint over its members would no longer apply to the UK.

\section{ACCESS TO JUSTICE IN ENVIRONMENTAL MATTERS}

A vital element that has contributed over the years to effective environmental governance and protection in the UK is the opportunity its citizens have to call their government to account, through EU mechanisms, once it falls short on its environmental obligations under EU law. 'Even when they become costly to implement, difficult to achieve or obstruct what have emerged as more important current priorities', states must still adhere to EU environmental laws, otherwise, 'there are means (slow and imperfect though they are) for using the [European] Court of Justice [of the European Union (CJEU)] to seek compliance. ${ }^{, 70}$ Although, in this regard, individuals and private entities have no direct access to the ECJ, they can file a complaint with the EC which can commence an infringement proceeding before the CJEU against the state failing to comply with EU law. ${ }^{71}$ Indeed, about half of the actions in the CJEU instigated by the EC where initiated on the basis of public complaints sent to the EC about member states' violation of EU Law. ${ }^{72}$ And, as with most EU member states, this

\footnotetext{
67 See FISHER, L. and HARRISON, J. 'Beyond the Binary: Brexit, Environmental Law, and an Interconnected World', OUPblog, 19 September 2016, available at: http://blog.oup.come/2016/09/binarybrexit-environmental-law/.

68 See EUR-Lex, 'Environment and Climate Change', available at: http://eurlex.europa.eu/summary/chapter/environment.html?root_default=SUM_1_CODED\%3D20.

${ }^{69}$ Fisher and Harrison (n 67).

70 REID, C. T., 'Brexit and the Future of UK Environmental Law', Journal of Energy \& Natural Resources Law, vol. 34, num. 4, 2016, p. 413. See generally, HEDEMANN-ROBINSON, M. Enforcement of European Union Environmental Law: Legal Issues and Challenges, $2^{\text {nd }}$ ed., Routledge, 2015.

${ }^{71}$ See TFEU, Art 258; and LANE, J-E. 'European Union: The Legal Dimension', in VAN DER HOEK, M. P. (ed), Handbook of Public Administration and Policy in the European Union, Taylor \& Francis, 2005, p. 235.

${ }^{72}$ MILLER, V., 'Taking a Complaint to the Court of Justice of the European Union' (House of Commons Library, SN/IA/5397, 11 March 2010), p. 4.
} 
has helped the CJEU play a major role in protecting the UK environment from the actions of its government, ${ }^{73}$ and ensuring its compliance with procedural environmental norms. ${ }^{74}$

Beyond having (indirect) access to the CJEU, when private entities approach a domestic court in the UK to enforce government compliance with EU-related environmental obligations, EU law ensures that they are not completely left alone to the dictates of the national legal system. In this regard, their right of access to justice is enhanced by the fact that the domestic court is bound to follow the judgement of the CJEU on the matter or, when in doubt as to the interpretation or validity of an EU law, ask the CJEU for guidance and clarification. ${ }^{75}$ The effect of this complementary role of the CJEU is exemplified in the case of $R$ (ClientEarth) $v$ Secretary of State for the Environment, Food and Rural Affairs ${ }^{76}$ were the guidance provided by the CJEU assisted the national Supreme Court in holding that the UK government was in breach and must comply with its obligation under EU air quality law, contrary to the initial judgements of the UK High Court and Court of Appeal. ${ }^{77}$

However, post-Brexit, this vital EU regional platform for accessing justice in environmental matters will no longer be available to the UK public as it will lose its jurisdiction over the country. ${ }^{78}$ The CJEU's complementary role in assisting national courts will also cease, despite the UK's intention to retain applicable EU environmental laws. While in this regard the UK government appears glad to "take back control of our

\footnotetext{
${ }^{73}$ See for example, JACOBS, F. 'The Role of the European Court of Justice in the Protection of the Environment', Journal of Environmental Law, vol. 18, num. 2, 2016, pp. 1850-205; and Case C-304/15 Commission v UK, ECLI:EU:C:2016:706 (21 September 2016).

${ }^{74}$ See EBBESSON, J. 'The EU and the Aarhus Convention: Access to Information, Public Participation in Decision-Making and Access to Justice in Environmental Matters' (Briefing, European Parliament, June 2016) 8, available at: http://www.europarl.europa.eu/RegData/etudes/BRIE/2016/571357/IPOL_BRI(2016)571357_EN.pdf.

75 TFEU, Art 267. See also, CURIA, 'Your Questions on the Court of Justice of the European Union' (CJEU Press and Information, September 2010).

76 [2015] UKSC 28.

${ }^{77}$ HESLOP, A. 'R (ClientEarth) v Secretary of State for the Environment, Food and Rural Affairs',TFL Transport Emissions Roadmap Workshop, May 2015, p. 3.

${ }^{78}$ Her Majesty's Government, 'Enforcement and Dispute Resolution: A Future Partnership Paper' (UK Government, 2017) 1-2, available https://www.gov.uk/government/uploads/system/uploads/attachment_data/file/639609/Enforcement_and_ dispute_resolution.pdf.
} 
laws' ${ }^{79}$ the environmental implication of foreclosing the public's right of access to this regional court is quite significant. Principle 10 of the Rio Declaration $1992,{ }^{80}$ which is widely adopted, ${ }^{81}$ clearly supports the point that effective access to judicial proceedings 'at the relevant level' is vital for adequately addressing environmental issues. More so, improving access to justice and environmental dispute resolution is obviously critical for realising the UN's 2030 Agenda for Sustainable Development ${ }^{82}$ and the Sustainable Development Goals (SDGs), ${ }^{83}$ particularly SDG Goal 16 - 'to provide access to justice for all and build effective, accountable and inclusive institutions at all levels. ${ }^{84}$ Arguably, the relevant levels for effective environmental protection and dispute resolution, broadly speaking, are tripartite in nature - the national, regional and international levels. And it is quite worrisome that the UK public will have the regional aspect of their right of access to justice significantly whittled down as a result of Brexit.

Indeed, whilst the UK public can still resort to national courts to hold the government accountable with respect to the latter's environmental commitments, national courts have their limitations in this regard (and this is partly why supranational courts are relevant). For instance, Reid has demonstrated how ' $[\mathrm{t}]$ he debates and uncertainty about the status and enforceability of ... specific and legally binding greenhouse gas reduction targets in the $[\mathrm{UK}]$ Climate Change Acts show the difficulties in calling governments to account within the domestic legal structures. ${ }^{85}$ Its neutral and independent scrutiny, and its detachment from the political structures and dynamic of the UK or any other state, are some of the vital protective features which the CJEU brings to the table. In addition,

\footnotetext{
${ }^{79}$ BBC, 'Brexit: Theresa May says UK leaving EU Court's Jurisdiction', BBC, 23 August, 2017, available at: http://www.bbc.com/news/uk-politics-41012265.

${ }^{80}$ Rio Declaration on Environment and Development, adopted by the UN Conference on Environment and Development (UNCED), 3-14 June 1992, (1992) 31 ILM 874.

${ }^{81}$ See HÄNDL, G., 'Human Rights and Protection of the Environment: A Mildly "Revisionist" View', in TRINDADE, C. (ed), Human Rights, Sustainable Development and the Environment, IIDH/BID, 1992, pp. 139-140; and HÄNDL, G., 'Declaration of the United Nations Conference on the Human Environment (Stockholm Declaration), 1972 and the Rio Declaration on Environment and Development, 1992' (UN Audiovisual Library of International Law 2012), 6 <http://untreaty.un.org/cod/avl/pdf/ha/dunche/dunche_e.pdf> accessed 11 October, 2017.

${ }^{82}$ Available at: <http://www.un.org/sustainabledevelopment/development-agenda/> accessed 10 October, 2017.

83 Available at: <http://www.un.org/sustainabledevelopment/sustainable-development-goals/> accessed 10 October, 2017.

${ }^{84}$ Emphasis added.

85 REID, C., ob. cit., p. 414, referencing for more details -REID, C. T. 'A New Form of Duty? The Significance of "Outcome" Duties in the Climate Change and Child Poverty Acts', Public Law, num 4, 2012, pp. 749-767.
} 
the CJEU can mandate a government in breach of environmental law to pay fines until the compliance issues are resolved ${ }^{86}$ - this effective remedial and deterrence tool is unavailable to domestic courts in the UK. Given that the existing UK legal structures may be ineffective in filling the void that would be left by the CJEU, commentators are calling on the UK to 'explore new avenues to ensure better law enforcement' ${ }^{87}$ postBrexit. According to Busch QC:

post-Brexit much thought will require to be given... to procedural matters, including in particular those relating to the means of securing compliance with the requirements of EU law and challenging instances of non-compliance. This in turn is likely to give rise to collateral issues concerning, for instance, issues of standing, and of course the costs of environmental litigation. ${ }^{88}$

Even where the UK holds under international law similar environmental responsibilities to those within EU law, compliance mechanisms at that level - such as the International Court of Justice - hardly provides ample opportunity for action by non-state entities against a state compared to the right of access private entities have under EU law. ${ }^{89}$ Even where private entities can approach an international compliance mechanism with respect to environmental dispute, again, unlike the CJEU: it is either the mechanism has the weaknesses of a lack of mandatory jurisdiction and a confidential procedure, as is the case with the Permanent Court of Arbitration with regards to its Optional Rules for Arbitration of Disputes Relating to Natural Resources and/or the Environment which it launched in $2001 ;^{90}$ or, its decisions are merely recommendatory and non-binding like those of the Aarhus Convention Compliance Committee. ${ }^{91}$

${ }^{86}$ CARDESA-SALZMANN, A. and Annalisa SAVARESI, A. 'Law Enforcement Implications', in CARDESA-SALZMANN, A. and SAVARESI, A. ob. cit., p. 3.

${ }^{87}$ Ibid.

88 BUSCH, L. 'Brexit and Environmental Law: The Future', Landmark Chambers, October 2016, available http://www.landmarkchambers.co.uk/userfiles/documents/resources/Brexit\%20and\%20Environmental\%2 0Law\%201016\%20LBQC.pdf.

${ }^{89}$ See KALAS, P. K., 'International Environmental Dispute Resolution and the Need for Access by NonState Entities', Colorado Journal of International Environmental Law and Policy, num. 12, 2001, p. 191; and PEDERSEN, O. W., 'An International Environmental Court and International Legalism', Journal of Environmental Law, vol. 24, num. 3, 2012, p. 551.

90 See generally, RATLIFF, D. P. 'The PCA Optional Rules for Arbitration of Disputes Relating to Natural Resources and/or the Environment', Leiden Journal of International Law, num. 14, 2001, p. 887.

${ }^{91}$ See Aarhus Convention, Art 15; and Meeting of the Parties to the Aarhus Convention, 'Decision 1/7: Review of Compliance', doc. ECE/MP.PP/2/Add.8, 2 April 2004, available at: http://www.unece.org/fileadmin/DAM/env/pp/documents/mop1/ece.mp.pp.2.add.8.e.pdf. 
Nevertheless, the above gloomy picture of the future status of the UK public's right to access justice at supra-national levels in an environmental context, does not represent the entire image of 'tomorrow' in this regard. Beyond the CJEU and the Aarhus Convention Compliance Committee, the European Court of Human Rights (ECtHR), established under the European Convention on Human Rights (ECHR), ${ }^{92}$ provides a ray of hope. Importantly, individuals have direct access to the ECtHR (although, only after exhausting domestic judicial remedies), 'without any domestic or international intermediary, ${ }^{93}$ for the purpose of holding state parties accountable even in matters pertaining to the environment. ${ }^{94}$ Indeed, it is widely recognised, ${ }^{95}$ including under the Aarhus Convention, ${ }^{96}$ that environmental rights, especially its procedural aspects, are intrinsically linked to certain traditional human right norms. This point the ECtHR has demonstrated in several cases - such as McGinley and Egan v United Kingdom ${ }^{97}$ and Taskin $v$ Turkey ${ }^{98}$ - showing that established human right norms can and does constitute, to an extent, an alternative route for the public to assert their procedural environmental rights in the least.

Whilst it has been clearly argued that Brexit will lead to a loss within the domestic legal system of the UK of a stronger remedy against acts violating ECHR rights in procedural

\footnotetext{
92213 U.N.T.S. 221, 4 November 1950, Section II. The ECHR is an international human rights treaty adopted within the context of the Council of Europe and agreed to by the body's 47 member states.

${ }^{93}$ KEOHANE, R. O. et al, 'Legalized Dispute Resolution: Interstate and Transnational', in GOLDSTEIN, J. L. et al (eds), Legalization and World Politics, MIT Press, 2001, pp. 73-81. However, see ECtHR Art 35 that provides for the exhaustion of local remedies before an individual can approach the ECtHR.

${ }^{94}$ ECHR, Art 34.

${ }^{95}$ See APPELSTRAND, M. 'Participation and Societal Values: The Challenge for Lawmakers and Policy Practitioners', Forest Policy and Economics, num. 4, 2002, pp. 281, 283; and HANDL, G. 'Human Rights and Perfection of the Environment', in EIDE, A, KRAUSE, C, and ROSAS, A, (eds.), Economic, Social and Cultural Rights, Kluwer Law International, 2001, pp. 303, 318.
}

${ }^{96}$ See Preamble, paras. 6, 7, and 8.

97 [1998] III ECHR. In this case, the ECtHR reiterated the point that where government engages or permits hazardous activities with potential adverse effects for health, it has a positive obligation under Article 8 of the ECHR (on the right to private and family life) to ensure 'effective and accessible' procedures that enables relevant persons to obtain all relevant information (ibid, paras 97, 101.)

98 [2006] 42 EHRR 50. The ECtHR in this case which concerned the licensing of a mine, held that 'whilst Article 8 [of the ECHR which provides for the right to private and family life] contains no explicit procedural requirements, the decision-making process leading to measures of interference must be fair and such as to afford due respect to the interests of the individual as safeguarded by Article 8'(Ibid, para. 118.) The Court's subsequent emphasis in that passage on taken due account of the 'views' of individuals and its position that such individuals must be able to challenge a decision in court 'where their comments have not been given sufficient weight in the decision-making process' (Ibid, para. 119) does indicate quite clearly that public participation in the decision-making process will be essential for compliance with Article 8 of the ECHR. 
environmental matters, ${ }^{99}$ in light of the above analysis, the UK public can continue even after Brexit to fully explore the regional ECtHR judicial platform in asserting their environmental procedural rights. The latter position is so, giving that the $\mathrm{UK}$ is party to the ECHR and that this status will not be directly affected by its exit from the EU, as the latter is a different institution from the Council of Europe that adopted and is responsible for the ECHR. That said, an issue of concern is that since being a signatory to the ECHR is a requirement for EU membership, Brexit does remove a key obstacle to the UK withdrawing from the ECHR. ${ }^{100}$ This concern is not unfounded. The British Prime Minister, Theresa May, and the UK Conservative party feels that the UK may need to reconsider its membership of the ECHR in the future, after the conclusion of Brexit, perhaps, in order to retain at home more decision-making powers. ${ }^{101}$ Therefore, civil society must continue to pressure both this and successive UK governments to drop any idea of withdrawing from the ECHR considering the major restriction that such an action will further place on the public's right to hold their government to account in environmental matters. In addition to the above, it has also been well noted that Brexit will.

\section{SOME CROSS-CUTTING ISSUES}

Beyond the specific implications of Brexit for the individual pillars of procedural environmental rights elucidated above, UK exit from the EU may have some further effects or raise some pertinent concerns that generally cut across the various pillars.

One of the concerns which Brexit raises relates to the impact of devolution on the development of procedural environmental laws within the UK. Here, 'devolution' means that certain powers or competences are reserved to be exercised by the various component nations of the UK - England, Scotland, Wales, and Northern Island - and

\footnotetext{
${ }^{99}$ This domestic effect will vary within the UK, given the fact that the ECHR has different legal strength in Scotland, as opposed to England for example. MORGERA, E., CARDESA-SALZMANN, A., MCHARG, A., GEELHOED, M. and NTONA, M., Rights Protected under EU Law Concerning the Environment, Scottish Universities Legal Network on Europe, October 2016, p. 6.

100 EILSTRUP-SANGIOVANNI, M., 'Brexit and the Future of the European Convention on Human Rights', E-International Relations, 5 July, 2017, available at: http://www.e-ir.info/2017/07/05/brexit-andthe-future-of-the-european-convention-on-human-rights/.

${ }^{101}$ HOPE, C., 'Britain to be bound by European human rights laws for at least another five years even if Tories win election', The Telegraph, 18 May, 2017, available at: http://www.telegraph.co.uk/news/2017/05/18/britain-bound-european-human-rights-laws-least-anotherfive/.
} 
this has been a part of governance in the UK for many years now. ${ }^{102}$ The 'environment' is however one of the specific areas where power is devolved and the various component nations are free to legislate on it, albeit subject to the framework established by EU environmental law on the subject-matter. ${ }^{103}$ Therefore, while there may be some differences in the (procedural) environmental laws of each of the devolved administrations, the scale of divergence is limited and at a healthy level because of the harmonising force of EU law, as anything done by the devolved authorities in breach of EU framework on a subject is invalid. ${ }^{104}$ Thus, the existing level of coordination and harmony in UK environmental law in general is, to a sizable extent, a result of the EU influence.

However, this will no longer be the case post-Brexit. The various devolved units will largely be legally free to develop their laws relating to the environment in fundamentally different ways and directions. ${ }^{105}$ To be sure, '[p]roviding the room for difference is, of course, one of the major justifications for and benefits of devolution..., but too much disparity and fragmentation can have negative consequences.' ${ }^{106}$ Such major divergence in law and policy could arise from the fact that the different component nations have distinct views on environment issues, or in response to new problems, or even as a consequence of the nations' different administrative structures, etc. ${ }^{107}$ For example they could: vary the timescale for response to a request for environmental information; develop varying scopes on the proposed activities to which public participation should apply in their decision-making processes; and the current difference in rules as regards access to justice in environmental matter in England and Wale on the one hand, and Scotland on the other hand, could be further widened. Such sharp distinctions in regulations could possibly create complication, for instance, when

\footnotetext{
${ }^{102}$ See DEACON, R. Devolution in the United Kingdom, $2^{\text {nd }}$ ed., Edinburgh: Edinburgh University Press, 2012; and BOGDANOR, V., Devolution in the United Kingdom, Oxford: Oxford University Press, 2001.

${ }^{103}$ PAUN, A. 'Brexit, Devolution and Common Frameworks' (The Institute for Government, 19 October 2017) available at: https://www.instituteforgovernment.org.uk/explainers/brexit-devolution-and-commonframeworks.

${ }^{104}$ REID, C. T., 'Brexit and the Devolution Dynamics', Environmental Law Review, vol. 19, num. 1, 2017, pp. 3 - 4.

105 Ibid.

${ }^{106}$ House of Commons Environmental Audit Committee, 'Written Evidence Submitted by Colin T. Reid, Professor of Environmental Law, University of Dundee' (AEP0001, November 2015), available at: http://data.parliament.uk/writtenevidence/committeeevidence.svc/evidencedocument/environmentalaudit-committee/assessment-of-euuk-environmental-policy/written/24036.pdf.

${ }^{107}$ REID, C. T., ob. cit., pp. 4-5.
} 
dealing with cross-border issues. Hopefully, this will be a good reason to maintain some 'continued coordination and cooperation... [b]ut mechanisms for this must be established.' ${ }^{108}$ Yet, overall, the risk of losing some environmental benefits of the largely integrated and coordinated regulation experienced by the UK under the EU system, remains.

More than that, the likely increased variations in the procedural environmental laws of the devolved units raises some concerns as to whether the UK could be held noncompliant with the Aarhus Convention. Parties are obliged under Article 3 (1) of the Convention to "maintain and establish a clear... and consistent framework to implement the [Convention]' ${ }^{109}$ In fact, in a case concerning Croatia, ${ }^{110}$ certain laws on public participation that appeared to be in compliance with Article 7 of the Convention (which they sought to implement) were not consistent as to when public participation should take place with regards to certain plans. ${ }^{111}$ On this ground, the Aarhus Convention Compliance Committee held that Croatia 'failed to provide for a consistent and uniform application throughout the territory and is not clear as regards public participation... and therefore is not in compliance with [Article 3(1)]. ${ }^{112}$ Should such a perspective be applicable to the UK post-Brexit, it will be unable to successfully use its internal powersharing arrangement as an excuse for breach. This is because the Compliance Committee (relying on Article 27 of the 1969 Vienna Convention) has held in a matter concerning Belgium, ${ }^{113}$ that a Party cannot 'invoke its internal laws... including internal divisions of powers' as an excuse for not complying with the Convention. ${ }^{114}$

Going by existing rules and procedure in the UK, it does appear that such a situation may not be easy to resolve amiably between the UK and the devolved governments, unless a new coping mechanism is developed to address the issue. Reid puts it clearly:

[I]n contrast to the position with EU matters, the devolved authorities are not legally prohibited from acting in ways incompatible with international law. Instead compatibility with international obligations is ensured through the powers of the

\footnotetext{
${ }^{108} \mathrm{Ibid}, 5$.

${ }^{109}$ Emphasis added.

${ }^{110}$ Croatia ACCC/C/2012/66; ECE/MP.PP/C.1/2014/4, 13 January 2014.

${ }^{111}$ Ibid, paras 47 and $50-51$.

${ }^{112}$ Ibid, para 53.

${ }^{113}$ Belgium ACCC/2005/11; ECE/MP.PP/C.1/2006/4/Add.2, 28 July 2006.

${ }^{114}$ Ibid, para 41.
} 
Secretary of State to intervene. In order to prevent such incompatibility, s/he can prevent Bills going for Royal Assent, revoke subordinate legislation or direct that any other action is, or is not taken by the devolved administrations. This means that any disagreements are not calmed through resolution by the courts, but require political intervention which is likely only to exacerbate the dispute. ${ }^{115}$

Considering the above potential challenges that will unravel with a sharp differentiation of laws within the UK if devolved powers being 'repatriated' from the EU post-Brexit is not properly managed, the governments of the UK and devolved administrations have agreed on the need for new 'common frameworks' that will ensure regulatory consistency and coordination in some areas (like EU law does). ${ }^{116}$ It is however not clear if, or the extent to which this new 'common framework', when developed, will prevent a radical divergence in UK (procedural) environmental law as, according to Paun, 'the devil will be in the detail.,'117

Another related cross-cutting concern which Brexit raises is the possibility of a slowdown in the development of procedural environmental rights in the UK. As noted earlier, UK environmental law has on the whole witnessed significant, quick and positive transformation since the UK joined the EU. This has come about by the implementation of innovative EU environmental obligations in diverse areas including as it relates to public access to environmental information, ${ }^{118}$ among others. But while it

${ }^{115}$ REID, C. T., 'Taking Back Control from Brussels - But Where to?', OUPBlog, 7 November 2016, available at: https://blog.oup.com/2016/11/brexit-uk-eu-brussels/.

${ }^{116}$ See the Joint Ministerial Committee (EU Negotiations) Communiqué (16 October 2017), available at: https://www.gov.uk/government/uploads/system/uploads/attachment_data/file/652285/Joint_Ministerial_ Committee_communique.pdf.

117 PAUN, A. 'Finally a Brexit Breakthrough with the Devolved Nations' (The Institute for Government, 18 October 2017), available at: https://www.instituteforgovernment.org.uk/blog/finally-brexitbreakthrough-devolved-nations. The responses of some of the devolved governments to this idea of new 'common frameworks' although generally positive, maintains the uncertainty. According to the Welsh government, the need for such 'common frameworks' is recognised '[i]n some cases'. Welsh Government, 'Securing Wale's Future: Transiting from the European Union to a New Relationship with Europe' (The Welsh Government and Plaid Cymru, 2017) 26. For Scotland, there is acceptance that 'some common approaches' will be needed across the UK post-Brexit. Michael Russell, 'Minister for UK Negotiations on Scotland's Place in Europe - Statement to Parliament', 12 September 2017, available at: https://beta.gov.scot/publications/eu-withdrawal-bill-ministers-speech/. Also, Wales and Scotland take the firm position that such 'common frameworks' are 'a matter for negotiation and agreement between the governments concerned, not for imposition from Westminster' and they need to 'be based on common consent'. Respectively: Scottish Government, 'Scotland's Place in Europe' (The Scottish Government, December 2016) 41; and Welsh Government, ibid, 28. Moreover, 'while the UK and devolved governments agree on the overarching principles, there is no consensus yet on how the principles will be interpreted and where therefore frameworks will in practice be required.' PAUN, A. ob. cit.

118 See the EC Directive 2003/4/EC of 28 January 2003 on public access to environmental information (OJ L41/26), implemented in the UK by the Environmental Information Regulation 2004 (No. 3391), and the Environmental Information (Scotland) Regulations 2004 (No. 520). 
may be conceded that procedural rights in the UK would have changed significantly since the 1970s even without becoming an EU member state, ${ }^{119}$ Reid, in evidence given to the UK House of Commons Environmental Audit Committee, takes the frank position that ' $[\mathrm{t}$ ]he UK's membership of the EU has ensured environmental action was taken on a faster timetable and more thoroughly than would otherwise have been the case. ${ }^{120}$ This was largely achieved by EU pressure mechanisms which will to a large extent no longer be applicable to the UK post-Brexit.

What is more, with Brexit comes the risk of increased instability and vulnerability of procedural environmental rights to national pressures and politics, and perhaps, on a positive note, some opportunity for quicker and better targeted responses to changing environmental circumstances within the UK. Reid clearly captures this 'fluid' future:

It may take a frustratingly long time for laws to emerge from the EU, and then to be implemented by all the Member States, but once made they [usually] stick around. They are not as vulnerable to the short-term pressures of national politics as domestic legislation. The difficulty of revision [even though EU environmental law could sometime change rapidly] can mean that desirable improvements are not [easily] made, but the fact that the laws are not subject to constant chopping and changing [like national law] has its advantages. In particular, the stability of EU law [compared to national law in general] is well suited to tackling major environmental problems... where long term programmes and investments are needed to achieve substantial results. The... stability of environmental standards enables industry and investors to plan ahead and allows for the integration of different policy areas to be developed. The greater scope for rapid change that would follow Brexit brings both the advantages and disadvantages of flexibility, with the potential to respond more quickly to changing circumstances but also... [an increased] lack of certainty as to the future. ${ }^{121}$

\section{CONCLUSION}

The above analysis strongly suggests that the UK's exit from the EU will have a profound impact on procedural environmental rights in the UK. Spectacularly, and quite unexpectedly, the study revealed that some existing rights (apart from those applicable

\footnotetext{
${ }^{119}$ REID, C. T., ob. cit., p. 412.

${ }^{120}$ House of Commons Environmental Audit Committee ob. cit., p. 8.

${ }^{121}$ REID, C. T., ob. cit., 412 - 413.
} 
within the UK which will be retained after Brexit) may be maintained post-Brexit, such as the right of the UK public to access environmental held by EU institutions. The article also showed that Brexit could open new possibilities and opportunities for improved public involvement, like the public right to participate in environmental lawmaking processes particularly with respect to new law-making powers that will be 'repatriated' back to the UK from the EU. And this could arguably mean better compliance by the UK with its Aarhus Convention obligations in that regard.

However, the article found that Brexit majorly creates risks, challenges and uncertain for the future of procedural environmental rights in the UK, in terms of: the loss of EU administrative and judicial mechanisms for holding the UK government accountable for its environmental actions and omissions; the risk of extensive fragmentation and divergence in participation rights and opportunities with the return of some EU powers to devolved administrations; the potential for a slow-down in the development of procedural rights; the possibility of the lowering of standards in the implementation of Aarhus Convention rights domestically; the risk of violating the letter and spirit of the Aarhus Convention with the general degradation of procedural rights post-Brexit, among others.

No doubt, what is required to ensure a stable and progressive procedural environmental rights regime in the UK post-Brexit is beyond the current welcomed, but insufficient, move to retain presently applicable EU legal measures through the European Union (Withdrawal) Bill. The UK would need to move fast with respect to making new laws (where there was no domestic legislation) transposing relevant directly applicable EU laws in order to avoid the risk of regulatory uncertainty or lacuna. Also, to plug the accountability loop hole - to an extent - that will be created by the severance of relevant EU administrative and judicial mechanisms from the UK environmental governance structure, relatively domestic institutional adjustments need to be made and effective alternatives developed as earlier alluded to. In this light, among other measures, serious consideration needs to be given to creating an independent, expert body with some form of sanctioning powers for the purpose of scrutinising, with public involvement, government environmental actions and omissions. ${ }^{122}$

Additionally, the UK government must do everything possible to ensure that the current plan for a new arrangement between the various devolved administration to guarantee

${ }^{122}$ See LEE, M., ob. cit., p. 90. 
continued coordination and cooperation in environmental regulation, in order to prevent extreme divergence and fragmentation in approach, is fruitful and robust. Overall, more than ever before, the post-Brexit era would require a more active, dynamic and vigilant civil society to keep the pressure on government to ensure that procedural environmental rights neither lag behind international and regional best practices, nor are lowered in standard due to political or other considerations.

\section{REFERENCES}

APPELSTRAND, M. 'Participation and Societal Values: The Challenge for Lawmakers and Policy Practitioners', Forest Policy and Economics, num. 4, 2002.

ASTHANA, A. and MASON, R., 'Theresa May asks EU for two-year Brexit Transition Period', The Guardian, 22 September 2017, available at: https://www.theguardian.com/politics/2017/sep/22/theresa-may-asks-eu-for-two-yearbrexit-transition-period.

ASTHANA, A., QUINN, B. and MASON, R. 'UK Votes to Leave EU after Dramatic Night Divides Nation', The Guardian, 24 June 2016, available at: https://www.theguardian.com/politics/2016/jun/24/britain-votes-for-brexit-eureferendum-david-cameron.

BARLOW M. and HADLEY, E. 'Effects of a Brexit on Environmental Laws: Habitats, Waste, Chemicals and Air', Burges and Salmon, April 2016.

BBC, 'Brexit: Theresa May says UK leaving EU Court's Jurisdiction', $B B C, 23$ August, 2017, available at: http://www.bbc.com/news/uk-politics-41012265.

BOGDANOR, V., Devolution in the United Kingdom, Oxford: Oxford University Press, 2001.

BRINKHORST, L. 'Subsidiarity and European Community Environmental Policy: A Pandora's Box', European Environmental Law Review, 1993.

BUSCH, L. 'Brexit and Environmental Law: The Future', Landmark Chambers,

October 2016, available at: http://www.landmarkchambers.co.uk/userfiles/documents/resources/Brexit\%20and\%20 Environmental\%20Law\%201016\%20LBQC.pdf. 
CARDESA-SALZMANN, A. and Annalisa SAVARESI, A. 'Law Enforcement Implications', CARDESA-SALZMANN, A. and SAVARESI, A. The Implication of Brexit for Environmental Law in Scotland, Scottish Universities Legal Network on Europe, December 2016.

COMMONER, B., The Closing Circle: Confronting the Environmental Crisis, Jonathan Cape Ltd, 1972.

DE SADELEER, N. 'Principle of Subsidiarity and the EU Environmental Policy', Journal of European Environmental and Planning Law, vol. 9, num. 1, 2012.

DEACON, R. Devolution in the United Kingdom, $2^{\text {nd }}$ ed., Edinburgh: Edinburgh University Press, 2012.

DEHAN, A. 'An International Environmental Court: Should there be One?', Touro Journal of Transnational Law, num. 2, 1992.

EBBESSON, J. 'The EU and the Aarhus Convention: Access to Information, Public Participation in Decision-Making and Access to Justice in Environmental Matters' (Briefing, European Parliament, June 2016) 8, available at: http://www.europarl.europa.eu/RegData/etudes/BRIE/2016/571357/IPOL_BRI(2016)57 1357_EN.pdf.

EBBESSON, J., GAUGITSCH, H., JENDROSKA, J., MARSHALL, F. and STEC, S., The Aarhus Convention: An Implementation Guide, $2^{\text {nd }}$ ed., United Nations, 2014.

EILSTRUP-SANGIOVANNI, M., 'Brexit and the Future of the European Convention on Human Rights', E-International Relations, 5 July, 2017, available at: http://www.eir.info/2017/07/05/brexit-and-the-future-of-the-european-convention-on-human-rights/.

FISHER, L. and HARRISON, J. 'Beyond the Binary: Brexit, Environmental Law, and an Interconnected World', OUPblog, 19 September 2016, available at: http://blog.oup.come/2016/09/binary-brexit-environmental-law/.

HANDL, G. 'Human Rights and Perfection of the Environment', in EIDE, A, KRAUSE, C, and ROSAS, A, (eds.), Economic, Social and Cultural Rights, Kluwer Law International, 2001.

HÄNDL, G., 'Human Rights and Protection of the Environment: A Mildly "Revisionist" View', in TRINDADE, C. (ed), Human Rights, Sustainable Development and the Environment, IIDH/BID, 1992. 
HEDEMANN-ROBINSON, M. Enforcement of European Union Environmental Law: Legal Issues and Challenges, $2^{\text {nd }}$ ed., Routledge, 2015.

HESLOP, A. 'R (ClientEarth) v Secretary of State for the Environment, Food and Rural Affairs',TFL Transport Emissions Roadmap Workshop, May 2015.

HEYVAERT, V., 'Aarhus to Helsinki: Participation in Environmental Decision-Making on Chemicals', in PALLEMAERTS, M. (ed), The Aarhus Convention at Ten: Interactions and Tensions between Conventional International Law and EU Environmental Law, Groningen: Europa Law Publishing, 2011.

HOPE, C., 'Britain to be bound by European human rights laws for at least another five years even if Tories win election', The Telegraph, 18 May, 2017, available at: http://www.telegraph.co.uk/news/2017/05/18/britain-bound-european-human-rightslaws-least-another-five/.

HUNTER, A. and WHEELER, B., 'Brexit: All you need to know about the UK leaving the EU', BBC, 26 October 2017, available at: http://www.bbc.com/news/uk-politics32810887.

IMRIE, C. 'Scotland After Brexit: Environmental Law', University of Strathclyde International Public Policy Institute, May 2017.

JACKSON, T., Prosperity without Growth: Economics for a Finite Planet, Routledge, 2016.

JACOBS, F. 'The Role of the European Court of Justice in the Protection of the Environment', Journal of Environmental Law, vol. 18, num. 2, 2016.

KALAS, P. K., 'International Environmental Dispute Resolution and the Need for Access by Non-State Entities', Colorado Journal of International Environmental Law and Policy, num. 12, 2001.

KEOHANE, R. O. et al, 'Legalized Dispute Resolution: Interstate and Transnational', in GOLDSTEIN, J. L. et al (eds), Legalization and World Politics, MIT Press, 2001.

LANE, J-E. 'European Union: The Legal Dimension', in VAN DER HOEK, M. P. (ed), Handbook of Public Administration and Policy in the European Union, Taylor \& Francis, 2005. 
LEE, M. 'Accountability for Environmental Standards after Brexit' Environmental Law Review, vol. 19, num. 2, 2017.

LEE, R. G., 'Always Keep a Hold of the Nurse: British Environmental Law and Exit from the European Union', Journal of Environmental Law, num. 29, 2017.

MIKULI, P. and KUCA, G. 'The Public Hearing and Law-Making Procedure', Liverpool Law Review, num. 37, 2016.

MORGERA, E., CARDESA-SALZMANN, A., MCHARG, A., GEELHOED, M. and NTONA, M., Rights Protected under EU Law Concerning the Environment, Scottish Universities Legal Network on Europe, October 2016.

PAUN, A. 'Brexit, Devolution and Common Frameworks' (The Institute for Government, 19 October 2017) available at: https://www.instituteforgovernment.org.uk/explainers/brexit-devolution-and-commonframeworks.

PAUN, A. 'Finally a Brexit Breakthrough with the Devolved Nations' (The Institute for Government, 18 October 2017), available at: https://www.instituteforgovernment.org.uk/blog/finally-brexit-breakthrough-devolvednations.

PEDERSEN, O. W., 'An International Environmental Court and International Legalism', Journal of Environmental Law, vol. 24, num. 3, 2012.

RATLIFF, D. P. 'The PCA Optional Rules for Arbitration of Disputes Relating to Natural Resources and/or the Environment', Leiden Journal of International Law, num. $14,2001$.

REID, C. 'Procedural Rights', in CARDESA-SALZMANN, A. and SAVARESI, A. The Implication of Brexit for Environmental Law in Scotland, Scottish Universities Legal Network on Europe, December 2016.

REID, C. T., 'Brexit and the Devolution Dynamics', Environmental Law Review, vol. 19, num. 1, 2017.

REID, C. T., 'Brexit and the Future of UK Environmental Law', Journal of Energy \& Natural Resources Law, vol. 34, num. 4, 2016.

RODGERS, C. 'ELR opinion issue 3 2016: BREXIT: What implications for land use and the natural environment?', Environmental Law Review, vol. 18, num. 1, 2016. 
ROGER, A. 'Chemicals', in CARDESA-SALZMANN, A. and SAVARESI, A. The Implication of Brexit for Environmental Law in Scotland, Scottish Universities Legal Network on Europe, December 2016.

ROGER, A. 'Types of EU Environmental Legislation and Competence Allocation' in CARDESA-SALZMANN, A. and SAVARESI, A. The Implication of Brexit for Environmental Law in Scotland, Scottish Universities Legal Network on Europe, December 2016.

SAVARESI, A., 'Brexit Scenarios', in CARDESA-SALZMANN, A. and SAVARESI, A. The Implication of Brexit for Environmental Law in Scotland, Scottish Universities Legal Network on Europe, December 2016.

SCOTFORD, E. and BOWMAN, M., 'Brexit and Environmental Law: Challenges and Opportunities', King's Law Journal, vol. 27, num. 3, 2016.

THE WILDLIFE TRUST, 'A Guide to Key European Environmental 'Directives', available at: http://www.wildlifetrusts.org/EU-impact.

TROMANS, S. and BOWDEN, P. 'Brexit and Environmental Law: Exit from the Euratom Treaty and its Environmental Implications', UK Environmental Law Association, July 2017.

UNDP, 'Decentralization: A Sampling of Definitions' (October, 1999) 2, available at: http://web.undp.org/evaluation/documents/decentralization_working_report.PDF.

VAN ZEBEN, J. 'Subsidiarity in European Environmental Law: A Competence Allocation Approach', Harvard Environmental Law Review, num. 38, 2014. 